\title{
Effect of hyperandrogenism on ovarian function
}

\author{
Leandro M Velez ${ }^{1}$, Maria F Heber ${ }^{1}$, Silvana R Ferreira ${ }^{1}$, Giselle A Abruzzese ${ }^{1}$, Roxana M Reynoso ${ }^{2}$ \\ and Alicia B Motta ${ }^{1}$ \\ ${ }^{1}$ Laboratorio de Fisio-patología Ovárica, Centro de Estudios Farmacológicos y Botánicos (CEFYBO), \\ Consejo Nacional de Investigaciones Científicas y Técnicas (CONICET) and ${ }^{2}$ Laboratorio de Endocrinología, \\ Departamento de Fisiología, Facultad de Medicina, Universidad de Buenos Aires, Buenos Aires, Argentina \\ Correspondence should be addressed to A B Motta; Email: aliciabmotta@yahoo.com.ar
}

\begin{abstract}
The objective of this work was to study the ovarian function when follicular development is induced during a hyperandrogenic condition. Female rats were injected with either equine chorionic gonadotropin (eCG group) to induce folliculogenesis or eCG together with DHEA to induce folliculogenesis in a hyperandrogenic condition (eCG + HA group). The control group was injected with vehicle. Ovarian mRNA levels of the peroxisome proliferator-activated receptor gamma (PPAR $\gamma$ ) co-activator PGC1 $\alpha$, the PPAR $\gamma$ co-repressor NCoR, the


and cyclooxygenase 2 (COX2) were evaluated only by real-time PCR. COX2 was evaluated by both real-time PCR and western blot. Serum steroid hormones and both the oxidative and inflammatory statuses were also quantified. We found that eCG-induced folliculogenesis induced increased mRNA levels of PGC1 $\alpha$ and decreased those of NCoR when compared with controls. In addition, we found an increase in serum estradiol $\left(E_{2}\right)$ levels and enhanced mRNA expression of CYP19A. A pro-inflammatory status and a pro-oxidant status were also established. When folliculogenesis was induced in a hyperandrogenic condition, the mRNA levels of the PPAR $\gamma$ co-repressor NCoR remained higher than in controls and the pro-inflammatory and pro-oxidant statuses were enhanced. In addition, the enzymes involved in ovarian steroidogenesis were altered leading to the accumulation of testosterone and an unfavorable $E_{2} /$ testosterone ratio. These alterations led to abnormal follicular development.
\end{abstract}

Reproduction (2015) 149 577-585

\section{Introduction}

Fuel sensors, such as metabolites (e.g., glucose, fatty acids, and amino acids) and hormones (e.g., insulin, leptin, and ghrelin), are involved in the regulation of fertility at each level of the hypothalamic-pituitarygonadal axis (Froment et al. 2006). The discovery of the peroxisome proliferator-activated receptor (PPAR) family of transcription factors revealed the link between lipid/ glucose availability and long-term metabolic adaptation (Issemann \& Green 1990). PPARs have three subtypes, $\alpha$, $\beta / \delta$, and $\gamma$ (Issemann \& Green 1990, Komar 2005), which are detected in the ovary of several species, including the rat (Komar 2005). PPAR $\gamma$ is expressed primarily in the granulosa cells of developing follicles (Komar \& Curry 2002), where it regulates the synthesis of steroid hormones (Huang 2008). At the end of follicular development, the luteinizing hormone surge downregulates the expression of ovarian PPAR $\gamma$ (Komar et al. 2001, Froment et al. 2003). In the rat, PPARr expression is low in newly forming luteal tissue and higher in luteal tissue present from previous ovulations (Komar \& Curry 2002).
PPAR $\gamma$ is activated by binding either to endogenous factors (such as prostaglandins (PGs) or fatty acids) or to exogenous factors (including non-steroidal anti-inflammatory drugs, fibrates, polycyclic aromatic hydrocarbons, traditional medicines, and thiazolidinediones (such as pioglitazone and rosiglitazone)) (Yu et al. 1995, Jaradat et al. 2001, Lim \& Dey 2002, McIntyre et al. 2003, Seli \& Duleba 2004, Huang et al. 2005, Kanayama et al. 2005, Kim et al. 2005, Banerjee \& Komar 2006). In addition, PPAR $\gamma$ inactivation can be prevented by thiazolidinediones (Choi et al. 2010, Kono et al. 2012).

The binding of PPAR $\gamma$ to ligands modulates its transcriptional activity by increasing the recruitment of co-activators, such as PGC1 $\alpha$ (Puigserver et al. 1998), but, in the absence of ligands, the recruitment of co-repressors, as NCoR, down-regulates the transcriptional activity of PPAR $\gamma$ (Yu et al. 2005). After its activation, PPAR $\gamma$ modulates lipid metabolism (Curti et al. 2011) and the inflammatory response (Celinski et al. 2012, Rezvanfar et al. 2012), whereas, during folliculogenesis, PPAR $\gamma$ modulates steroidogenesis and cellular proliferation (Froment et al. 2006). Given the 
important role of the PPAR $\gamma$ system in modulating endocrine and metabolic pathways, the management of the PPAR $\gamma$ system represents a fundamental tool in treating metabolic disorders.

PGs modulate different ovarian functions, such as the rupture of ovarian follicles associated with ovulation (Husein \& Kridli 2003, Medan et al. 2003) and luteolysis (Motta et al. 1999, 2001). We have previously reported that hyperandrogenism induces a pro-inflammatory status mediated by the PG system in both mice (Luchetti et al. 2004, Elia et al. 2006) and rats (Amalfi et al. 2012). It has been recently reported that, in breast cancer, a PPAR $\gamma$ agonist inhibits P450 aromatase expression by means of the inhibition of the PGE pathway (Margalit et al. 2012).

Hyperandrogenism also induces an increase in the production of reactive oxygen species by the ovary, thus altering oxidant-antioxidant balance (Luchetti et al. 2004, Diamanti-Kandarakis \& Economou 2006, Elia et al. 2006).

In this work, we studied the effect of hyperandrogenism on the regulation of ovarian function. Specifically, we designed a murine model that allowed us to investigate events linked to early follicular development. We studied: i) the histology of ovarian tissue, ii) the transcript levels of the PPAR $\gamma$ co-activator PGC1 $\alpha$ and the PPAR $\gamma$ co-repressor NCoR, iii) the main enzymes involved in ovarian steroidogenesis: CYP17, $3 \beta$-hydroxysteroid dehydrogenase ( $3 \beta$-HSD), $17 \beta-\mathrm{HSD}$, and CYP19A, iv) the serum levels of progesterone, testosterone, and estradiol $\left.\left(E_{2}\right), v\right)$ the ovarian inflammatory status characterized by both the gene and protein expression of cyclooxygenase 2 (COX2), the limiting enzyme of PG synthesis, and the ovarian PGE content, and vi) the systemic oxidant-antioxidant balance, evaluated by the lipid peroxidation index and by the production of the antioxidant metabolite glutathione (GSH) in serum samples.

\section{Materials and methods}

\section{Animal model}

The animal model consisted of immature (22-25 days old) female Sprague-Dawley rats intraperitoneally injected with $25 \mathrm{IU}$ of chorionic gonadotropin (eCG; Sigma-Aldrich) in $0.1 \mathrm{ml}$ saline solution (eCG group) (Faut et al. 2011). The hyperandrogenized (HA) group consisted of rats intraperitoneally injected with $25 \mathrm{IU} /$ rat eCG together with a s.c. injection of $60 \mathrm{mg} / \mathrm{kg}$ body weight of DHEA (Sigma-Aldrich) in $0.1 \mathrm{ml}$ sesame oil (eCG + HA group). The control group consisted of rats injected with vehicle (sesame oil). Rats were housed under controlled temperature $\left(22^{\circ} \mathrm{C}\right)$ and illumination $(14 \mathrm{~h}$ light:10 $\mathrm{h}$ darkness cycle; lights on at $0500 \mathrm{~h}$ ) and allowed to access Purina rat chow and water freely. All procedures involving animals were conducted in accordance with the Animal Care and Use Committee of Consejo Nacional de Investigaciones Científicas y Técnicas (CONICET, Argentina).
This study was approved by the Ethics Committee of the School of Medicine of University of Buenos Aires (Argentina). In this model of follicular development, the peak of ovarian steroidogenesis is obtained $8 \mathrm{~h}$ after eCG treatment (Faut et al. 2011). Thus, rats were anesthetized with carbon dioxide and killed by decapitation after $8 \mathrm{~h}$ of treatments. Trunk blood was collected and serum was separated by centrifugation at $1000 \mathrm{~g}$ for $15 \mathrm{~min}$ and stored at $-80{ }^{\circ} \mathrm{C}$ until progesterone, $\mathrm{E}_{2}$, testosterone, lipid peroxidation index, and GSH levels were determined. Ovarian tissue from a total of 20 rats from each group was used as follows: ten freshly dissected ovaries from different rats were immediately fixed in $4 \%(\mathrm{w} / \mathrm{v})$ paraformaldehyde for morphological studies, whereas other 30 were frozen at $-80^{\circ} \mathrm{C}$. Of the latter, ten were used for mRNA analysis by real-time PCR, ten for western blotting, and ten for PGE quantification by RIA.

\section{Histological studies of ovarian tissue}

To study the effect of hyperandrogenization on early folliculogenesis, serial sections of ten ovaries from each of the three groups and from different animals, fixed as described earlier in this study, were consecutively cut $(5 \mu \mathrm{m} / \mathrm{section})$, placed on gelatin-coated slides (Biobond, British Biocell International, Cardiff, UK), air dried for $2 \mathrm{~h}$, and fixed for $5 \mathrm{~min}$ in acetone at $4{ }^{\circ} \mathrm{C}$. Then, consecutive sections from each ovary were washed in PBS $\left(137 \mathrm{mmol} / \mathrm{I} \mathrm{NaCl}, 2.7 \mathrm{mmol} / \mathrm{I} \mathrm{KCl}, 4.3 \mathrm{mmol} / \mathrm{l} \mathrm{Na}{ }_{2}\right.$ $\mathrm{HPO}_{4} .7 \mathrm{H}_{2} \mathrm{O}, 1.4 \mathrm{mmol} / / \mathrm{KH}_{2} \mathrm{PO}_{4}$, and $\mathrm{pH} 7.3$ ) and stained with hematoxylin and eosin (DAKO Corporation, Carpinteria, CA, USA) for histological analysis. This resulted in 200 sections for each ovary. Histological serial sections were analyzed independently by three of the authors, and ovarian follicles were classified and quantified. Follicular atresia was also quantified.

\section{Gene expression analysis}

To determine whether hyperandrogenism altered the gene expression of NCoR, PGC1 $\alpha$, CYP17, 3 $\beta-\mathrm{HSD}, 17 \beta-\mathrm{HSD}$, CYP19A, and COX2, their mRNA levels were measured by real-time PCR analysis. Total mRNA from ovarian tissue from the control, eCG, and eCG + HA groups was extracted using RNAzol RT (MRC gene, Molecular Research Center, Cincinnati, OH, USA) following the manufacturer's instructions. cDNA was synthesized from $400 \mathrm{ng}$ mRNA using random primers. real-time PCR analysis was performed from this CDNA by means of the real mix B124-100 (Biodynamics SRL, Buenos Aires, Argentina) and those primers according to the analysis. The amplified products were quantified by fluorescence using the Rotor Gene 6000 Corbett. Results are expressed in arbitrary units. The primers are shown in Table 1.

\section{Western blotting}

Ovarian tissue was lysed for $20 \mathrm{~min}$ at $4{ }^{\circ} \mathrm{C}$ in lysis buffer $(20 \mathrm{mM}$ Tris- $-\mathrm{HCl}, \mathrm{pH}$ 8.0, $137 \mathrm{mM} \mathrm{NaCl}, 1 \%$ Nonidet P-40, and $10 \%$ glycerol) supplemented with protease inhibitors $(0.5 \mathrm{mM}$ phenylmethylsulphonyl fluoride, $0.025 \mathrm{mM} \mathrm{N}$-CBZ-L-phenylalanine chloromethyl ketone, $0.025 \mathrm{mM} \mathrm{N}$-p-tosyl-lysine chloromethyl ketone, and $0.025 \mathrm{mM} \mathrm{L-1-tosylamide-2-phenyl-}$ 
Table 1 List of primers used in real-time PCR.

\begin{tabular}{lll}
\hline Genes & Forward primer $\left(5^{\prime}-3^{\prime}\right)$ & Reverse primer $\left(5^{\prime}-3^{\prime}\right)$ \\
\hline Ncor1 & TAT CGG AGC CAT CTT CCC AC & ACT TGG GTA TCC TGG GGT TG \\
Ppargc1a & AAT GCA GCG GTC TTA GCA CT & GTG TGA GGA GGG TCA TCG TT \\
Ptgs2 & ATG AGT ACC GCA AAC GCT TC & CCC CAA AGA TAG CAT CTG GA \\
Rpl32 & TGG TCC ACA ATG TCA AGG & CAA AAC AGG CAC ACA AGC \\
Cyp17a1 & TCT CAT TAC ACC CAC GCA GA & CGG GGC AGT TGT TTA TCA TC \\
Hsd3b & GAC ACC CCT CAC CAA AGC TA & TTG TAA AAT GGA CGC AGC AG \\
Hsd17b1 & TCT CAT TAC ACC CAC GCA GA & CGG GGC AGT TGT TTA TCA TC \\
Cyp19a1 1 & CCT GGC AAG CAC TCC TTA TC & CCA CGT CTC TCA GCG AAA AT \\
\hline
\end{tabular}

ethylchloromethyl ketone). The lysate was centrifuged at $4{ }^{\circ} \mathrm{C}$ for $10 \mathrm{~min}$ at $10000 \mathrm{~g}$ and the pellet discarded. Protein concentrations in the supernatant were measured by the Bradford assay (Bio-Rad). After boiling for $5 \mathrm{~min}, 90 \mu \mathrm{g}$ of each protein were applied on an SDS-polyacrylamide gel (10\%) and electrophoresis was performed at $100 \mathrm{~V}$ for $1.5 \mathrm{~h}$. The separated proteins were transferred onto nitrocellulose membranes in a transfer buffer (20\% methanol, vol/vol; $0.19 \mathrm{M}$ glycine; $0.025 \mathrm{M}$ Tris-Base, and $\mathrm{pH} 8.3$ ) for $1 \mathrm{~h}$ at $4{ }^{\circ} \mathrm{C}$. Blots were blocked for $1.5 \mathrm{~h}$ in TBS $(4 \mathrm{mM}$ Tris- $\mathrm{HCl}, \mathrm{pH} 7.5$, and $100 \mathrm{mM} \mathrm{NaCl})$ containing BSA $(0.1 \%)$ at room temperature. Rabbit polyclonal anti-COX2 (Santa Cruz Biotechnology, Inc.; 1:200 overnight) was used as a primary antibody. Rainbowcolored protein mass markers (14.3-200 kDa, Bio-Rad) were applied to samples to determine the bands. The band corresponding to COX2 is at $72 \mathrm{kDa}$. Protein bands were visualized by incubating the blots with a biotin-conjugated secondary anti-rabbit IgG $(1: 5000,1 \mathrm{~h})$ followed by streptavidin-peroxidase complex and diaminobenzidine solution. The consistency of protein loading was evaluated by staining the membranes with Ponceau-S and applying the protein $\beta$-actin (42 kDa; Sigma Co.). The intensities (area $\times$ density) of the individual bands were quantified by densitometry (Model GS-700, Imaging Densitometer, Bio-Rad). The experiment was independently repeated three times. Results are expressed in arbitrary units.

\section{Progesterone, $E_{2}$, and testosterone RIAs}

Serum progesterone and $\mathrm{E}_{2}$ levels were determined by specific RIA as described previously (Amalfi et al. 2012). Briefly, serum samples from ten rats per treatment were extracted with the same volume of diethyl ether three times. The extracts were collected and evaporated in a vacuum oven, and stored at $-80{ }^{\circ} \mathrm{C}$ until the RIA was performed. The antibodies from progesterone and $\mathrm{E}_{2}$ were provided by Dr Niswender (Colorado State University, Fort Collins, CO, USA). Both sensitivities were 5-10 pg/tube. The intra- and inter-assay coefficients of variation were, respectively, 10.9 and $12.8 \%$ for progesterone and 5.0 and $10.0 \%$ for $E_{2}$. Results are expressed in ng progesterone or $\mathrm{E}_{2} / \mathrm{ml}$ serum.

Testosterone was quantified by RIA as described previously (Amalfi et al. 2012). Briefly, serum samples were extracted as described for progesterone and $E_{2}$. The utility range of the assay was $25-1600 \mathrm{pg}$. The intra- and inter-assay variations were 7.5 and $15.1 \%$ respectively, and the cross-reaction between testosterone and DHEA was $<0.01 \mathrm{pg}$. Results are expressed in $\mathrm{pg}$ testosterone/ml serum.

\section{PG RIA}

Ovarian PGE content was determined by RIA as reported previously (Motta et al. 1999). Results are expressed in $\mathrm{pg} / \mu \mathrm{g}$ protein. Protein concentration in ovarian tissue was determined by the Bradford method (Bradford 1976).

\section{Oxidative stress-related parameters}

\section{Lipid peroxidation}

The amount of malondialdehyde (MDA) formed from the breakdown of polyunsaturated fatty acids was measured as an index of peroxidation (Motta et al. 2001). Results are expressed as content of MDA (nmol MDA formed/ml serum).

\section{GSH content}

The antioxidant metabolite GSH was quantified as described previously (Elia et al. 2006). The reduced form of GSH comprises the bulk of cellular protein sulfhydryl groups. Results are expressed in $\mu \mathrm{mol} \mathrm{GSH} / \mathrm{ml}$ serum.

\section{Statistical analysis}

Statistical analyses were performed using the Instant program (GraphPad Software, San Diego, CA, USA). ANOVA followed by Tukey's test was used to compare all pairs of columns. The Bonferroni's correction for multiple testing was used to adjust the threshold for statistical significance to $P<0.05$.

\section{Results \\ Ovarian histology}

Ovaries from the control group showed a total of $5440 \pm$ 120 follicles while ovaries from the eCG group had $11115 \pm 150$ follicles and those from the eCG $+\mathrm{HA}$ group had $8350 \pm 140$ follicles. The ovarian follicles were classified and quantified as primordial (PrF), primary (PF), secondary (SF), and antral follicles (AF) (Fig. 1A). The percentage of PrF was higher in the eCG group than in controls and that corresponding to eCG $+\mathrm{HA}$ group was higher than in the eCG and control groups (Fig. 1A). PF was lower in the eCG + HA group than in the eCG and control groups (Fig. 1A). The percentage of atretic follicles decreased in the eCG when compared with control (Fig. 1B), while that in the eCG + HA group did not differ from that in the eCG or control groups (Fig. 1B). 

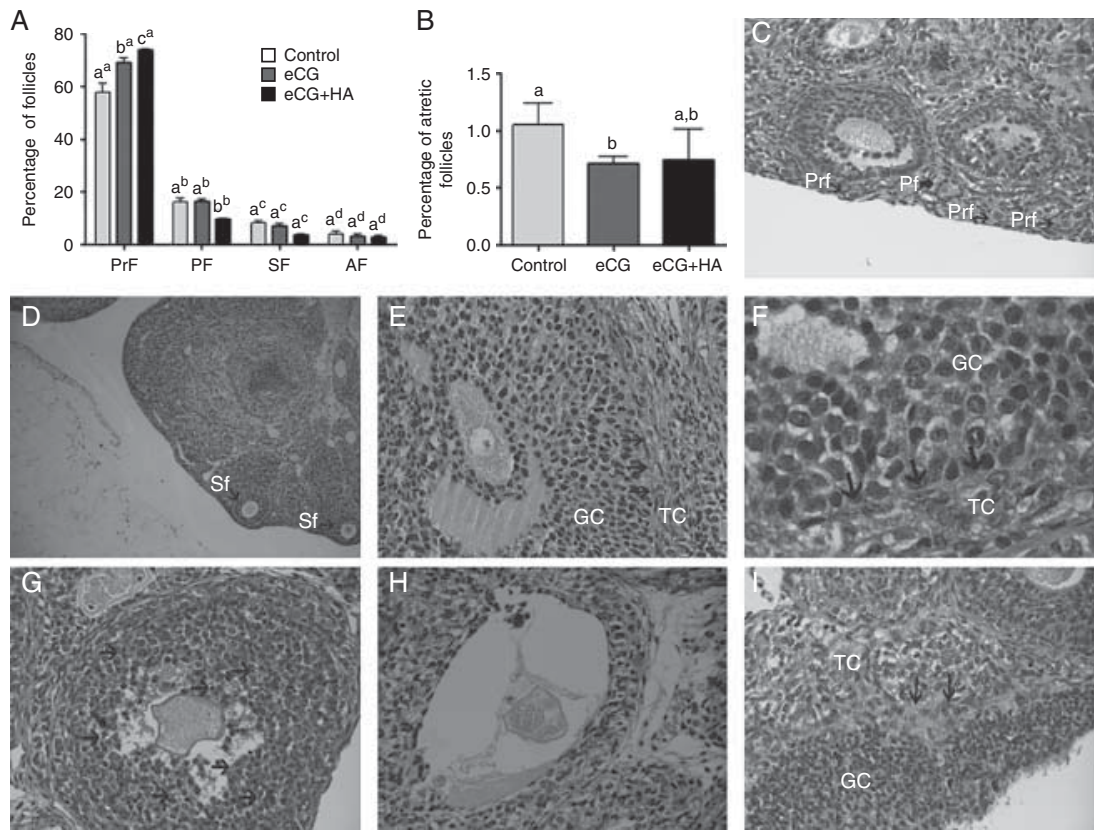

Figure 1 (A) Percentages of the different ovarian follicles present in the ovaries of control, eCG, and eCG $+\mathrm{HA}$ rats. $\mathrm{a}^{\mathrm{a}} \neq \mathrm{b}^{\mathrm{a}} \neq \mathrm{C}^{\mathrm{a}}: P<0.05$ and $\mathrm{a}^{\mathrm{b}} \neq \mathrm{b}^{\mathrm{b}}$ : $P<0.05$. Superscript letters a, b, c and d are used to represent statistical analysis in PrF, PF, SF and AF respectively. (B) Percentage of atretic follicles found in the ovaries of the three groups of rats. $a \neq b \neq c$ : $P<0.05$. (C) PrF (thin arrows) and PF (thick arrows) from an ovary of a rat from the eCG group rats. Magnification: $\times 100$. (D) SF (black arrows) from an ovary of a rat of the eCG group. Magnification: $\times 40$. (E) A healthy antral follicle $(A F)$ from a rat of the eCG group. Black arrows show the lamina basal between granulosa cell (GC) and theca cell (TC). Magnification: $\times 100$. (F) Healthy AF from a rat of the eCG group showing the basal lamina (black arrows) between GC and TC. Magnification: X125. (G) An atretic AF from a rat of the eCG + HA group. Black arrows show some of the numerous pyknotic bodies present throughout the granulosa layer. Magnification: $\times 100$. (H) An AF from a rat of the eCG $+\mathrm{HA}$ group rats in a later stage of atresia. Note the absence of granulosa layer and the deformation of the oocyte. Magnification: $\times 100$. (I) A non-healthy AF from a rat of the eCG + HA group showing the invasion (black arrows) of theca layer (TC) over granulosa (GC) cells. Magnification: $\times 100$.

The histological examination of ovaries from the eCG group showed the following: PrF were located in the ovarian cortex, formed by an oocyte surrounded by a flattened layer of pre-granulosa cells (Fig. 1C); PF presented at least one cuboidal layer of granulosa cells (Fig. 1C); SF showed more than one layer of cuboidal granulosa cells and an incipient theca layer (Fig. 1D); and AFs presented a cavity called antrum, a fully grown oocyte with the surrounded zona pellucida, and a basal lamina between granulosa and theca cells (Fig. 1E); AF showed good differentiation of the basal lamina (Fig. 1F).

The histological examination of ovaries from the eCG+HA group showed increased follicular atresia, detected mainly in AFs. In addition, degenerative changes were observed in granulosa cells, which shrank and became evident as pyknotic bodies (Fig. 1G). In a later stage of atresia, the oocyte showed signs of reinitiated meiosis and fragmentation with decreased or absent granulosa layer (Fig. 1H). In addition, we found invasion of the theca cells over granulosa cells (Fig. 1I).

\section{Effect of hyperandrogenism on the PPAR system}

The induction of ovarian folliculogenesis decreased the mRNA levels of the PPAR $\gamma$ co-repressor NCoR (Fig. 2A) and increased the mRNA levels of the PPAR $\gamma$ co-activator, PGC1 $\alpha$ (Fig. 2B), when compared with controls. In the hyperandrogenic condition $(\mathrm{eCG}+\mathrm{HA}$ group), the mRNA levels of NCoR increased and remained high relative to those of the control and eCG groups (Fig. 2A), whereas the mRNA levels of PGC1 $\alpha$ decreased to control values (Fig. 2B).

\section{Effect of hyperandrogenism on enzymes involved in the ovarian steroidogenesis}

Folliculogenesis induced by eCG did not modify the mRNA levels of CYP17 (Fig. 3A), 3 $\beta$-HSD (Fig. 3B), or $17 \beta-\mathrm{HSD}$ (Fig. 3C), but increased the mRNA levels of CYP19A, an enzyme that synthesizes $E_{2}$ from testosterone (Fig. 3D). In the hyperandrogenic condition, the mRNA levels of CYP17, 3 $\beta$-HSD, and 17 $\beta$-HSD (Fig. 3A, $B$ and $C$ respectively) significantly increased when compared with both the control and eCG groups whereas those of CYP19A decreased to control values (Fig. 3D).

\section{Effect of hyperandrogenism on progesterone, testosterone, and $E_{2}$ levels}

Folliculogenesis induced by eCG increased serum progesterone levels (Fig. 4A), did not modify serum testosterone levels (Fig. 4B), and increased serum $E_{2}$ 

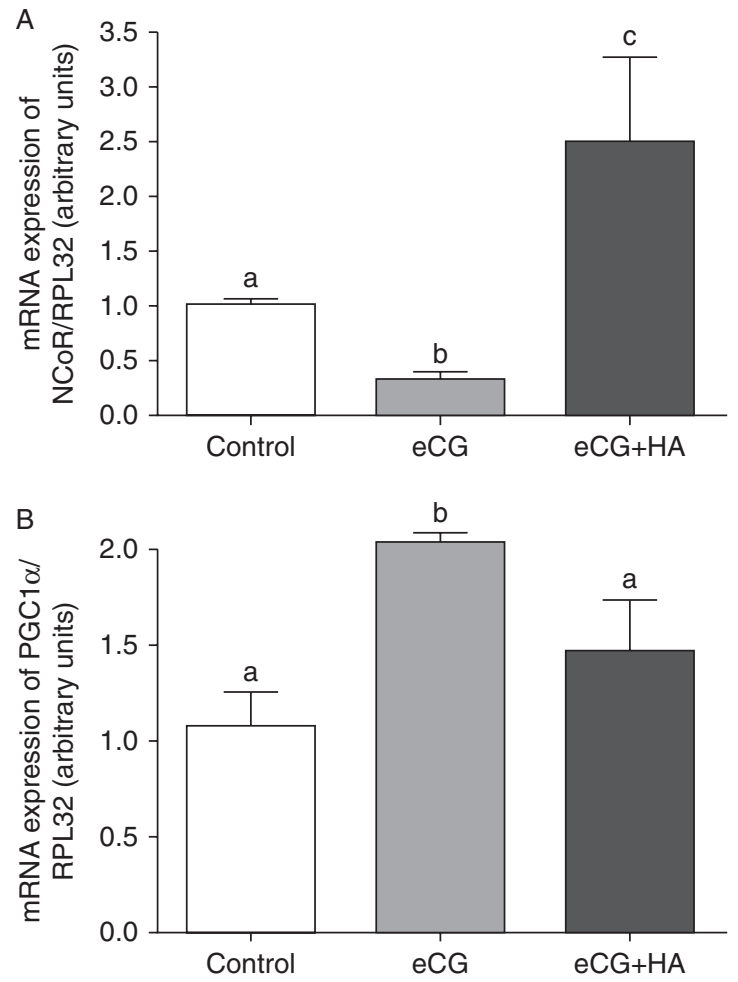

Figure 2 Effect of hyperandrogenism on the peroxisome proliferatoractivated receptor gamma (PPAR $\gamma$ ) system. Graph corresponding to the integrated optical density of (A) mRNA of the PPAR $\gamma$ inhibitor NCoR from the control, eCG, and eCG + HA groups determined by real-time PCR; a vs b: $P<0.001$; a vs $b$ and $b$ vs c: $P<0.0001$ by ANOVA test and (B) mRNA of the PPAR $\gamma$ activator PGC $1 \alpha$, a vs b: $P<0.001$ by ANOVA test. Each column represents the mean \pm s.E.M. of ten measurements from different animals.

levels when compared with controls (Fig. 4C). In the hyperandrogenic condition, progesterone levels decreased to control values (Fig. 4A), while testosterone levels increased when compared with both the control and eCG groups (Fig. 4B) and serum $\mathrm{E}_{2}$ levels increased when compared with the control and eCG groups (Fig. 4C). It is important to note that the $E_{2}$ /testosterone ratio, a marker of follicular development, increased with the induction of folliculogenesis (Fig. 4D) but decreased in the HA condition when compared with both the control and eCG groups (Fig. 4D).

\section{Effect of hyperandrogenism on the ovarian pro-inflammatory status}

The ovarian pro-inflammatory status was evaluated by the mRNA and protein levels of COX2 and by the ovarian content of PGE. Folliculogenesis induced by eCG increased both mRNA (Fig. 5A) and protein (Fig. 5B, $\mathrm{C}$ and D) levels of COX2 and ovarian PGE content (Fig. 5E) when compared with control, whereas folliculogenesis induced in a hyperandrogenic condition (eCG + HA) increased both mRNA (Fig. 5A) and protein
(Fig. 5B, C and D) levels of COX2 and PGE content (Fig. 5E) when compared with the eCG group.

\section{Effect of hyperandrogenism on circulating oxidant-antioxidant balance}

Regarding the ovarian oxidant-antioxidant balance, the lipid peroxidation index was evaluated by the content of ovarian MDA and the antioxidant response by the ovarian content of GSH. Neither MDA content nor GSH content was modified by the induction of folliculogenesis (Fig. 6A). However, when folliculogenesis was induced in a hyperandrogenic condition, MDA content was higher and GSH content was lower than in the eCG and control groups (Fig. 6A and $\mathrm{B}$ respectively).

\section{Discussion}

The battery of animal models used for the study of polycystic ovaries has allowed the different aspects of the pathology to be focused. In that context, the letrozole model in rats is suitable to mimic the ovarian features of human polycystic ovary syndrome (PCOS), while the dihydrotestosterone model is suitable for studies of both ovarian and metabolic features of the syndrome (Mannerås et al. 2007). In agreement with these findings, our previous findings (Luchetti et al. 2004, Elia et al. 2006, Faut et al. 2011) and data presented herein reveal that the DHEA model in rats induces a polycystic phenotype that allows to focus on both ovarian and metabolic aspects.

The PPAR $\gamma$ system is strongly expressed in granulosa cells, where it regulates early folliculogenesis (Komar 2005, Froment et al. 2006). For this reason, the PPARr system has been the focus of several studies on


Figure 3 Effect of hyperandrogenism on enzymes involved in ovarian steroidogenesis. Graph corresponding to the integrated optical density of mRNA from the control, eCG, and eCG $+\mathrm{HA}$ groups determined by real-time PCR of (A) CYP17, a vs b: $P<0.001$; (B) $3 \beta-H S D$, a vs b: $P<0.001$; (C) 17 $\beta-$ HSD, a vs b: $P<0.0001$; and (D) CYP19A, a vs b: $P<0.0001$ by ANOVA test. Each column represents the mean \pm s.E.M. of ten measurements from different animals. 

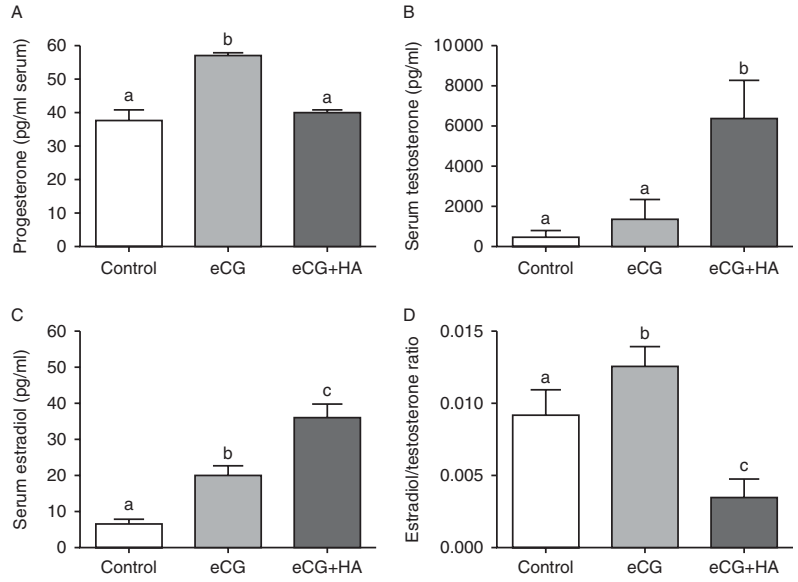

Figure 4 Effect of hyperandrogenism on serum progesterone, testosterone, and estradiol $\left(E_{2}\right)$ levels and $E_{2} /$ testosterone ratio. Serum levels of (A) progesterone, (B) testosterone, (C) $\mathrm{E}_{2}$, and (D) $\mathrm{E}_{2}$ /testosterone ratio from the control, eCG, and eCG + HA groups. Each column represents the mean \pm S.E.M. of ten measurements from different animals: $a$ vs $b$ : $P<0.001$ and b vs c: $P<0.0001$ by ANOVA.

physiological and metabolic/endocrine disorders. In fact, a direct association between polymorphisms in the genes encoding PPARs and hyperandrogenism has been recently reported (San-Millan \& Escobar-Morreale 2010). It has also been reported that the treatment with synthetic PPARr ligands improves endocrine and metabolic disorders in women with PCOS (luorno \& Nestler 1999, Girard 2001, Seli \& Duleba 2004, Minge et al. 2006, Brannian et al. 2008). The PPARy system regulates the expression of genes required for follicular development, ovulation, oocyte maturation, and corpus luteum development (Jablonka-Shariff et al. 1999, Lim et al. 1999, Feige et al. 2005, Froment et al. 2006). Long et al. (2009) found that mRNA for PPAR $\gamma$ was undetectable on day 1 , low from days 5 to 14 , and increased by day 19 post partum. Although folliclestimulating hormone (FSH) receptor has also been detected earlier, it has been found that FSH is not a primary factor initiating the expression of PPAR $\gamma$ and that other agents play a role in activating its expression in the ovary (Long et al. 2009). Although the complete mechanism of ovarian PPAR $\gamma$ activation remains unknown as yet, it has been reported that, to act, PPAR $\gamma$ has to be free from its inhibitor NCoR and, to recruit, its activator PGC1 $\alpha$ (Jablonka-Shariff et al. 1999, Lim et al. 1999, Feige et al. 2005, Froment et al. 2006).

In a previous report (Faut et al. 2011), we found that, during early folliculogenesis, gene and protein expression of PPAR $\gamma$ and the protein STAR is increased when compared with controls. In this study, we found that the induction of follicular development altered steroidogenic enzymes downstream of STAR: while CYP17A1, HSD3B, and HSD17B1 were not modified by eCG treatment, Cyp19a1, the gene corresponding to the enzyme that converts testosterone into $E_{2}$, increased.

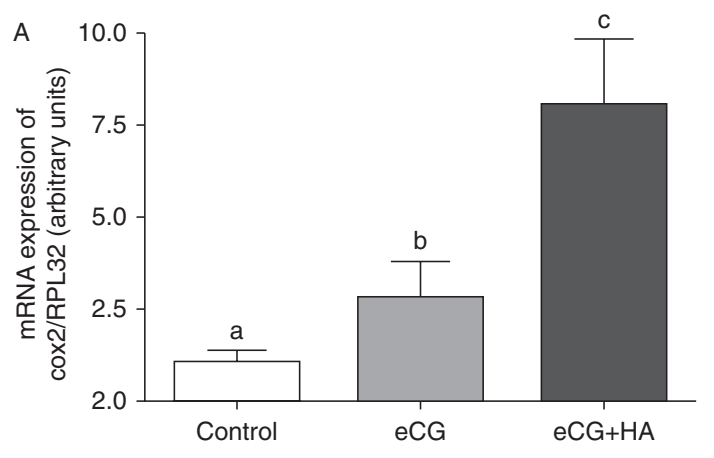

B



C

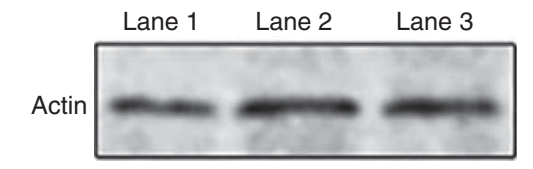

D

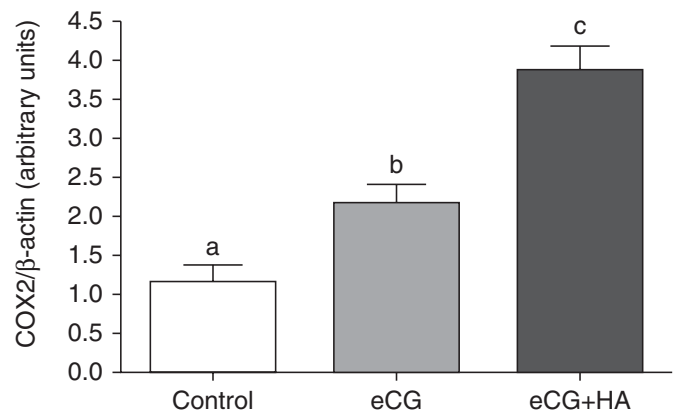

$\mathrm{E}$

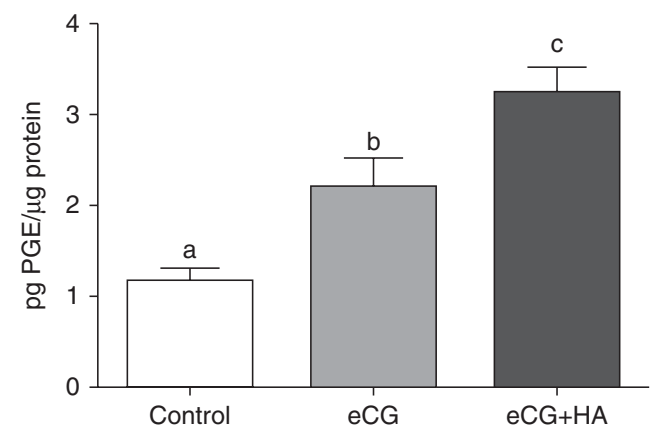

Figure 5 Effect of hyperandrogenism on the inflammatory status. (A) Graph corresponding to the integrated optical density of mRNA of cyclooxygenase 2 (COX2) from the control, eCG, and eCG + HA groups determined by real-time PCR. Each column represents the mean \pm S.E.M. of ten measurements from different animals: $a$ vs $b$ : $P<0.0001$ and b vs c: $P<0.0001$ by ANOVA. (B) A representative western blot corresponding to protein expression of COX2 from the control, eCG, and eCG + HA groups compared with actin $(\mathrm{C})$, lane 1, control; lane 2, eCG; and lane 3, eCG + HA, and (D) graph corresponding to the integrated optical density of COX2 protein from the control, eCG, and eCG + HA groups determined by western blot. Each column represents the mean \pm s.E.M. of ten measurements from different animals: a vs b: $P<0.0001$ and b vs c: $P<0.0001$ by ANOVA. (E) Ovarian content of prostaglandin E (PGE) determined by RIA. Each column represents the mean \pm S.E.M. of ten measurements from different animals: a vs b: $P<0.0001$ and b vs $c: P<0.0001$ by ANOVA. 

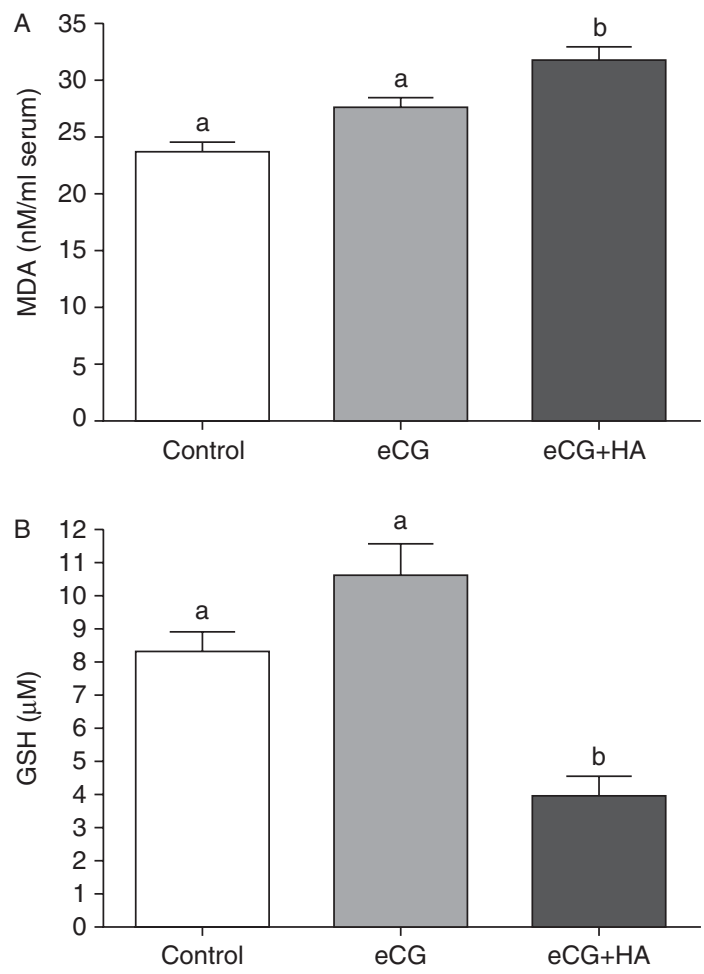

Figure 6 Effect of hyperandrogenism on oxidative stress. (A) Lipid peroxidation was evaluated by the quantification of malondialdehyde (MDA) levels and (B) concentration of antioxidant metabolite glutathione $(\mathrm{GSH})$ from the control, eCG, and eCG + HA groups. Each column represents the mean \pm s.E.M. of ten measurements from different animals: a vs b: $P<0.0001$ by ANOVA.

These data are in agreement with that reported by Gougeon (1996), according to which $E_{2}$ levels are essential during follicular development. In contrast, we have previously reported that when folliculogenesis is induced in a hyperandrogenic condition, the levels of both PPAR $\gamma$ and StAR decrease to control values (Faut et al. 2011), and herein, we demonstrated that all enzymes downstream of pregnenolone synthesis, i.e., CYP17, 3 $\beta-H S D$, and $17 \beta-H S D$, remained higher than in the control and eCG groups, except that corresponding to CYP19A, which showed the same pattern as the control group. Moreover, serum progesterone levels that increase during the induction of folliculogenesis decrease to control values during the hyperandrogenic condition. These data suggest the stimulation of ovarian steroidogenesis and the accumulation of testosterone during the induction of follicular development in a hyperandrogenic condition. This accumulation of testosterone and the adverse $\mathrm{E}_{2}$ /testosterone ratio, which have been reported to impair follicular development (Gougeon 1996), result in avoiding the production of the dominant follicle able to ovulate. In addition, Dumesic et al. (2007) reported that an altered
$\mathrm{E}_{2}$ /testosterone ratio is responsible for poor oocyte quality in prenatally HA female rhesus monkeys and sheep. Furthermore, Amato et al. (2011) reported that a low $E_{2} /$ testosterone ratio is associated with oligoanovulatory cycles in women with PCOS. In agreement with these findings, herein, we found that hyperandrogenism generates altered follicular development, represented by an increased percentage of PrF and a decreased percentage of $\mathrm{PF}$, suggesting accelerated follicular recruitment but in detriment of follicle development. Not only the percentage but also the total number of follicles were modified by hyperandrogenism. Ovaries from the eCG group showed an increased number of total follicles when compared with controls. This increased number of follicles decreased by hyperandrogenism when compared with those from the eCG group but remained higher than those from the control group.

The data of this study demonstrate, for the first time, that folliculogenesis induced by eCG in prepubertal rats results in increased gene expression of the PPAR $\gamma$ co-activator PGC1 $\alpha$ and in decreased gene expression of the co-repressor NCoR when compared with controls and that, in a hyperandrogenic condition, NCoR remains higher than in both the control and eCG groups and PGC1 $\alpha$ reaches control values. These results suggest that folliculogenesis induced by eCG activates the PPAR $\gamma$ transcriptional system. These findings and the fact that, during the hyperandrogenic condition, the mRNA levels of NCoR remain higher than those of controls, and that those of $\mathrm{PGC} 1 \alpha$ reach control values, suggest that the decreased ovarian PPAR $\gamma$ system induced by hyperandrogenism might be responsible for an ovarian environment unfavorable to generate pre-ovulatory follicles.

The role of PPAR $\gamma$ in ovarian steroidogenesis is associated with increased COX2 activity, which, in turn, enhances PG synthesis before ovulation (Duffy \& Stouffer 2001, Komar et al. 2001, Komar 2005, Banerjee \& Komar 2006, Brannian et al. 2008, Kim et al. 2008). In fact, we found that folliculogenesis induction increased both gene and protein expression of ovarian COX2 and that this correlated with enhanced ovarian PGE content. We also found that hyperandrogenism exacerbated these effects, a fact in agreement with our previous findings (Amalfi et al. 2012). Taking into account the results obtained herein, both in the PPAR $\gamma$ system and with respect to the $E_{2} /$ testosterone ratio, we suggest that high COX2 expression and PG synthesis would downregulate the PPAR $\gamma$ system, as in other systems (Banerjee \& Komar 2006).

During early folliculogenesis, apoptosis plays a fundamental role during early folliculogenesis. We have previously demonstrated that acute hyperandrogenism induces a pro-apoptotic status (Faut et al. 2011), which alters normal folliculogenesis. Therefore, prenatally HA rats display increased ovarian oxidative stress and an anovulatory estrous cycle during their adult life 
(Amalfi et al. 2012). In this study, we found that acute hyperandrogenism induces an imbalance in the oxidantantioxidant ratio characterized by increased systemic lipid peroxidation and decreased GSH levels. These data reveal a response of the antioxidant defenses against hyperandrogenism, which is in agreement with the so-called 'controlled response of GSH' reported previously (Amalfi et al. 2012).

In summary, our results demonstrate for the first time that an acute hyperandrogenic condition during follicular development alters the gene expression of the PPAR $\gamma$ co-repressor $\mathrm{NCoR}$ and co-activator PGC $1 \alpha$, generating an unfavorable environment that involves the dysregulation of the PPAR $\gamma$ system. We also found that the hyperandrogenic condition during follicular development enhances ovarian steroidogenesis, with the accumulation of testosterone and an activation of the pro-inflammatory status, and that it leads to establishment of a systemic pro-oxidant status.

\section{Declaration of interest}

The authors declare that there is no conflict of interest that could be perceived as prejudicing the impartiality of the research reported.

\section{Funding}

This study was supported by Agencia Nacional de Promoción Científica y Tecnológica (grant number PICT 71/2010, PICT 577/ 2012, and PICT 689/2013) and Consejo Nacional de Investigaciones Científicas y Técnicas (CONICET) PIP 185, Argentina.

\section{Acknowledgements}

The authors thank Enzo Cuba and Marcela Marquez for their technical support in animal care.

\section{References}

Amalfi S, Velez LM, Heber MF, Vighi S, Ferreira SR, Orozco AV, Pignataro O \& Motta AB 2012 Prenatal hyperandrogenization induces metabolic and endocrine alterations which depend on the levels of testosterone exposure. PLoS ONE 7 e37658. (doi:10.1371/journal.pone. 0037658)

Amato MC, Verghi M, Nucera M, Galluzzo A \& Giordano C 2011 Low estradiol-to-testosterone ratio is associated with oligo-anovulatory cycles and atherogenic lipidic pattern in women with polycystic ovary syndrome. Gynecological Endocrinology 27 579-586. (doi:10.3109/ 09513590.2010.495797)

Banerjee J \& Komar CM 2006 Effects of luteinizing hormone on peroxisome proliferator-activated receptor $\gamma$ in the rat ovary before and after the gonadotropin surge. Reproduction 131 93-101. (doi:10.1530/rep.1.00730)

Bradford MM 1976 A rapid and sensitive method for the quantitation of microgram quantities of protein utilizing the principle of protein-dye binding. Analytical Biochemistry 72 248-254. (doi:10.1016/00032697(76)90527-3)

Brannian JD, Eyster KM, Weber M \& Diggins M 2008 Pioglitazone administration alters ovarian gene expression in aging obese lethal yellow mice. Reproductive Biology and Endocrinology 6 10. (doi:10. 1186/1477-7827-6-10)
Celinski K, Dworzanski T, Fornal R, Korolczuk A, Madro A \& Slomka M 2012 Comparison of the anti-inflammatory and therapeutic actions of PPAR- $\gamma$ agonists rosiglitazone and troglitazone in experimental colitis. Journal of Physiology and Pharmacology 63 631-640.

Choi JH, Banks AS, Estall JL, Kajimura S, Bostrom P, Laznik D, Ruas JL, Chalmers MJ, Kamenecka TM, Bluher M et al. 2010 Anti-diabetic drugs inhibit obesity-linked phosphorylation of PPAR $\gamma$ by Cdk5. Nature $\mathbf{4 6 6}$ 451-456. (doi:10.1038/nature09291)

Curti ML, Jacob P, Borges MC, Rogero MM \& Ferreira SR 2011 Studies of gene variants related to inflammation, oxidative stress, dyslipidemia, and obesity: implications for a nutrigenetic approach. Journal of Obesity 2011 497401. (doi:10.1155/2011/497401)

Diamanti-Kandarakis E \& Economou F 2006 Stress in women: metabolic syndrome and polycystic ovary syndrome. Annals of the New York Academy of Sciences 1083 54-62. (doi:10.1196/annals.1367.006)

Duffy DM \& Stouffer RL 2001 The ovulatory gonadotrophin surge stimulates cyclooxygenase expression and prostaglandin production by the monkey follicle. Molecular Human Reproduction 7 731-739. (doi:10.1093/molehr/7.8.731)

Dumesic DA, Abbott DH \& Padmanabhan V 2007 Polycystic ovary syndrome and its developmental origins. Reviews in Endocrine \& Metabolic Disorders 8 127-141. (doi:10.1007/s11154-007-9046-0)

Elia E, Sander V, Luchetti CG, Solano ME, Di Girolamo G, Gonzalez C \& Motta AB 2006 The mechanisms involved in the action of metformin in regulating ovarian function in hyperandrogenized mice. Molecular Human Reproduction 12 475-481. (doi:10.1093/molehr/gal057)

Faut M, Elia EM, Parborell F, Cugnata NM, Tesone M \& Motta AB 2011 Peroxisome proliferator-activated receptor $\gamma$ and early folliculogenesis during an acute hyperandrogenism condition. Fertility and Sterility 95 333-337. (doi:10.1016/j.fertnstert.2010.07.1083)

Feige JN, Gelman L, Tudor C, Engelborghs Y, Wahli W \& Desvergne B 2005 Fluorescence imaging reveals the nuclear behavior of peroxisome proliferator-activated receptor/retinoid $\mathrm{X}$ receptor heterodimers in the absence and presence of ligand. Journal of Biological Chemistry 280 17880-17890. (doi:10.1074/jbc.M500786200)

Froment P, Fabre S, Dupont J, Pisselet C, Chesneau D, Staels B \& Monget P 2003 Expression and functional role of peroxisome proliferator-activated receptor- $\gamma$ in ovarian folliculogenesis in the sheep. Biology of Reproduction 69 1665-1674. (doi:10.1095/biolreprod.103.017244)

Froment P, Gizard F, Defever D, Staels B, Dupont J \& Monget P 2006 Peroxisome proliferator-activated receptors in reproductive tissues: from gametogenesis to parturition. Journal of Endocrinology 189 199-209. (doi:10.1677/joe.1.06667)

Girard J 2001 Mechanisms of action of thiazolidinediones. Diabetes \& Metabolism 27 271-278.

Gougeon A 1996 Regulation of ovarian follicular development in primates: facts and hypotheses. Endocrine Reviews 17 121-155. (doi:10.1210/ edrv-17-2-121)

Huang JC 2008 The role of peroxisome proliferator-activated receptors in the development and physiology of gametes and preimplantation embryos. PPAR Research 2008732303.

Huang TH, Kota BP, Razmovski V \& Roufogalis BD 2005 Herbal or natural medicines as modulators of peroxisome proliferator-activated receptors and related nuclear receptors for therapy of metabolic syndrome. Basic \& Clinical Pharmacology \& Toxicology 96 3-14. (doi:10.1111/j.17427843.2005.pto960102.x)

Husein MQ \& Kridli RT 2003 Effect of progesterone prior to GnRH-PGF2 $\alpha$ treatment on induction of oestrus and pregnancy in anoestrous Awassi ewes. Reproduction in Domestic Animals 38 228-232. (doi:10.1046/ j.1439-0531.2003.00411.x)

Issemann I \& Green S 1990 Activation of a member of the steroid hormone receptor superfamily by peroxisome proliferators. Nature 347 645-650. (doi:10.1038/347645a0)

luorno MJ \& Nestler JE 1999 The polycystic ovary syndrome: treatment with insulin sensitizing agents. Diabetes, Obesity \& Metabolism 127-136. (doi:10.1046/j.1463-1326.1999.00026.x)

Jablonka-Shariff A, Ravi S, Beltsos AN, Murphy LL \& Olson LM 1999 Abnormal estrous cyclicity after disruption of endothelial and inducible nitric oxide synthase in mice. Biology of Reproduction 61 171-177. (doi:10.1095/biolreprod61.1.171)

Jaradat MS, Wongsud B, Phornchirasilp S, Rangwala SM, Shams G, Sutton M, Romstedt KJ, Noonan DJ \& Feller DR 2001 Activation of 
peroxisome proliferator-activated receptor isoforms and inhibition of prostaglandin $\mathrm{H}(2)$ synthases by ibuprofen, naproxen, and indomethacin. Biochemical Pharmacology 62 1587-1595. (doi:10.1016/S00062952(01)00822-X)

Kanayama T, Kobayashi N, Mamiya S, Nakanishi T \& Nishikawa J 2005 Organotin compounds promote adipocyte differentiation as agonists of the peroxisome proliferator-activated receptor $\gamma /$ retinoid $X$ receptor pathway. Molecular Pharmacology 67 766-774. (doi:10.1124/mol.104. 008409)

Kim JH, Yamaguchi K, Lee SH, Tithof PK, Sayler GS, Yoon JH \& Baek SJ 2005 Evaluation of polycyclic aromatic hydrocarbons in the activation of early growth response- 1 and peroxisome proliferator activated receptors. Toxicological Sciences 85 585-593. (doi:10.1093/toxsci/kfi118)

Kim J, Sato M, Li Q, Lydon JP, Demayo FJ, Bagchi IC \& Bagchi MK 2008 Peroxisome proliferator-activated receptor $\gamma$ is a target of progesterone regulation in the preovulatory follicles and controls ovulation in mice. Molecular and Cellular Biology 28 1770-1782. (doi:10.1128/MCB. 01556-07)

Komar CM 2005 Peroxisome proliferator-activated receptors (PPARs) and ovarian function - implications for regulating steroidogenesis, differentiation, and tissue remodeling. Reproductive Biology and Endocrinology 3 41. (doi:10.1186/1477-7827-3-41)

Komar CM \& Curry TE Jr 2002 Localization and expression of messenger RNAs for the peroxisome proliferator-activated receptors in ovarian tissue from naturally cycling and pseudopregnant rats. Biology of Reproduction 66 1531-1539. (doi:10.1095/biolreprod66.5.1531)

Komar CM, Braissant O, Wahli W \& Curry TE Jr 2001 Expression and localization of PPARs in the rat ovary during follicular development and the periovulatory period. Endocrinology 142 4831-4838. (doi:10.1210/ endo.142.11.8429)

Kono T, Ahn G, Moss DR, Gann L, Zarain-Herzberg A, Nishiki Y, Fueger PT, Ogihara T \& Evans-Molina C 2012 PPAR- $\gamma$ activation restores pancreatic islet SERCA2 levels and prevents $\beta$-cell dysfunction under conditions of hyperglycemic and cytokine stress. Molecular Endocrinology 26 257-271. (doi:10.1210/me.2011-1181)

Lim H \& Dey SK 2002 A novel pathway of prostacyclin signaling - hanging out with nuclear receptors. Endocrinology 143 3207-3210. (doi:10. 1210/en.2002-220159)

Lim H, Gupta RA, Ma WG, Paria BC, Moller DE, Morrow JD, DuBois RN, Trzaskos JM \& Dey SK 1999 Cyclo-oxygenase-2-derived prostacyclin mediates embryo implantation in the mouse via PPAR $\delta$. Genes and Development 13 1561-1574. (doi:10.1101/gad.13.12.1561)

Long MJ, Sairam MR \& Komar CM 2009 Initiation of the expression of peroxisome proliferator-activated receptor $\gamma(\operatorname{PPAR} \gamma)$ in the rat ovary and the role of FSH. Reproductive Biology and Endocrinology 7145. (doi:10.1186/1477-7827-7-145)

Luchetti CG, Solano ME, Sander V, Arcos ML, Gonzalez C, Di Girolamo G, Chiocchio S, Cremaschi G \& Motta AB 2004 Effects of dehydroepiandrosterone on ovarian cystogenesis and immune function. Journal of Reproductive Immunology 64 59-74. (doi:10.1016/j.jri.2004.04.002)

Mannerås L, Cajander S, Holmäng A, Seleskovic Z, Lystig T, Lönn M \& Stener-Victorin E 2007 A new rat model exhibiting both ovarian and metabolic characteristics of polycystic ovary syndrome. Endocrinology 148 3781-3791. (doi:10.1210/en.2007-0168)

Margalit O, Wang D \& Dubois RN 2012 PPAR $\gamma$ agonists target aromatase via both PGE2 and BRCA1. Cancer Prevention Research 5 1169-1172. (doi:10.1158/1940-6207.CAPR-12-0365)
McIntyre TM, Pontsler AV, Silva AR, St Hilaire A, Xu Y, Hinshaw JC, Zimmerman GA, Hama K, Aoki J, Arai $\mathbf{H}$ et al. 2003 Identification of an intracellular receptor for lysophosphatidic acid (LPA): LPA is a transcellular PPAR $\gamma$ agonist. PNAS 100 131-136. (doi:10.1073/pnas. 0135855100)

Medan MS, Watanabe G, Sasaki K, Nagura Y, Sakaime H, Fujita M, Sharawy S \& Taya K 2003 Effects of passive immunization of goats against inhibin on follicular development, hormone profile and ovulation rate. Reproduction 125 751-757. (doi:10.1530/rep.0.1250751)

Minge CE, Ryan NK, Van Der Hoek KH, Robker RL \& Norman RJ 2006 Troglitazone regulates peroxisome proliferator-activated receptors and inducible nitric oxide synthase in murine ovarian macrophages. Biology of Reproduction 74 153-160. (doi:10.1095/biolreprod.105.043729)

Motta AB, Estevez A \& de Gimeno MF 1999 The involvement of nitric oxide in corpus luteum regression in the rat: feedback mechanism between prostaglandin $\mathrm{F}(2 \alpha)$ and nitric oxide. Molecular Human Reproduction 5 1011-1016. (doi:10.1093/molehr/5.11.1011)

Motta AB, Estevez A, Franchi A, Perez-Martinez S, Farina M, Ribeiro ML, Lasserre A \& Gimeno MF 2001 Regulation of lipid peroxidation by nitric oxide and PGF $2 \alpha$ during luteal regression in rats. Reproduction 121 631-637. (doi:10.1530/rep.0.1210631)

Puigserver P, Wu Z, Park CW, Graves R, Wright M \& Spiegelman BM 1998 A cold-inducible coactivator of nuclear receptors linked to adaptive thermogenesis. Cell 92 829-839. (doi:10.1016/S0092-8674 (00)81410-5)

Rezvanfar MA, Ahmadi A, Saadi HA, Baeeri M \& Abdollahi M 2012 Mechanistic links between oxidative/nitrosative stress and tumor necrosis factor $\alpha$ in letrozole-induced murine polycystic ovary: biochemical and pathological evidences for beneficial effect of pioglitazone. Human \& Experimental Toxicology 31 887-897. (doi:10.1177/0960327 111426589)

San-Millan JL \& Escobar-Morreale HF 2010 The role of genetic variation in peroxisome proliferator-activated receptors in the polycystic ovary syndrome (PCOS): an original case-control study followed by systematic review and meta-analysis of existing evidence. Clinical Endocrinology 72 383-392. (doi:10.1111/j.1365-2265.2009.03679.x)

Seli E \& Duleba AJ 2004 Treatment of PCOS with metformin and other insulin-sensitizing agents. Current Diabetes Reports 4 69-75. (doi:10. 1007/s11892-004-0014-8)

Yu K, Bayona W, Kallen CB, Harding HP, Ravera CP, McMahon G, Brown M \& Lazar MA 1995 Differential activation of peroxisome proliferatoractivated receptors by eicosanoids. Journal of Biological Chemistry $\mathbf{2 7 0}$ 23975-23983. (doi:10.1074/jbc.270.41.23975)

Yu C, Markan K, Temple KA, Deplewski D, Brady MJ \& Cohen RN 2005 The nuclear receptor corepressors NCoR and SMRT decrease peroxisome proliferator-activated receptor $\gamma$ transcriptional activity and repress 3T3-L1 adipogenesis. Journal of Biological Chemistry 280 13600-13605. (doi:10.1074/jbc.M409468200)

Received 2 February 2015

First decision 2 March 2015

Revised manuscript received 4 March 2015

Accepted 12 March 2015 